\title{
Peace Education Research in the Twenty First Century: Three concepts facing crisis or opportunity?
}

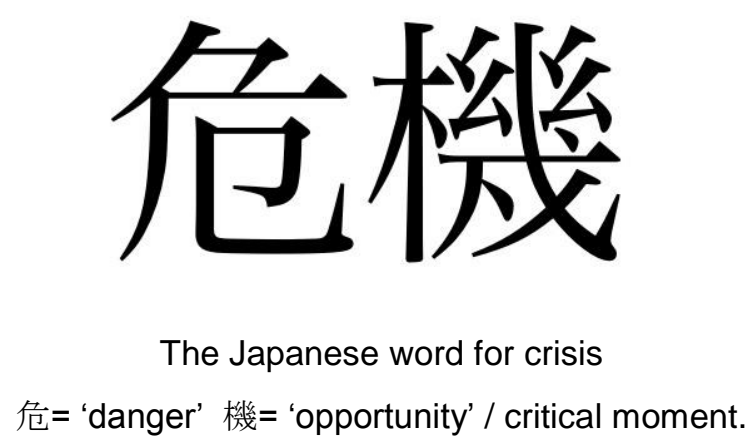

\subsection{Introduction}

It is hard to imagine anything more important than peace education, whether in conflictaffected areas or in countries that are free from open fighting (Sen, 2011, UNICEF, 2011), and yet the field, and its related research, faces substantial crises of legitimacy, representation and praxis. Some of these emanate from critiques of social science more generally, and some from the field of peace education itself. There are questions about what is meant by peace, about structural and cultural violence in educational institutions, and about the colonizing and hegemonic narratives that lurk beneath peace research and practice. These are potentially fatal to traditional concepts of research and evaluation (whose values?) research participants (participation in what?) and authorship (whose voice?). There are questions about whom peace educators speak for, and where they get their mandate. Equally, there are questions about how people's lives speak, and about what everyday choices say about lived attitudes towards peace. If peace education research is indeed facing a crisis, it might be useful to reflect on the fact that in many cultures the word crisis contains the notions of both danger and opportunity. The ideogram for 'crisis' in Japanese (shown at the top of this article) is an example of this, as is the Greek word 'kpírı' which has the idea of a decision or turning point at its heart. Are peace education and peace education research in the twenty first century facing danger, or are they facing a turning point, a time for decision, and an opportunity for change?

The current article is inspired by the work of llan Gur-Ze'ev. In 2011 he called for a systematic reflection on the conceptions and aims of peace education and peace education research. This was in response to philosophical challenges presented by post-structuralist philosophers. He was critical of attempts to achieve ethnocentric cohesion, urging instead a more fundamental review of what peace education might mean in these post-modern times. 
This article will review the three concepts of peace, education and research, and two further concepts that arise from combining peace with education, and peace education with research. It is concerned with crises of legitimation, representation and praxis, and with the structural and cultural violence that inhibit efforts towards a more inclusive global conception of peace. It will focus first briefly on peace studies, and then on education and then on peace education before turning to research and finally to peace education research. It will review the ways in which it may be possible to rise to Gur-Ze'ev's challenge, embracing new theoretical perspectives and methodologies that create synergies between research and aspirations towards positive (rather than negative) peace.

\section{2:1 The Crisis in Peace Studies}

The first little word in crisis is the word 'peace'. Johan Galtung, as far back as 1969, first made a distinction between positive and negative peace. He did this with reference to direct and indirect violence. Direct violence is conceived as physical aggression that can lead to physical harm or even death. Indirect violence is made up of structural and cultural factors. Structural violence is present in societies that are socially unjust (e.g. health inequalities) whilst cultural violence masks or validates structural violence (e.g. indifference or support of domestic violence) (cf. Guilherme \& Cremin, in press, Cremin et al 2012:430).

Thus negative peace is achieved by removing the threat of direct violence, whilst positive peace requires resolving issues of structural and cultural violence. (Guilherme \& Cremin, in press). Negative peace is achieved through peace-keeping initiatives, but positive peace is achieved through peace-making and peace-building. Peace-making takes place when a conflict has occurred, and peace-building takes place when there is a need to proactively reduce the likelihood of conflict occurring. Peace-keeping is easier to implement than peacemaking, and peace-building is the hardest of all because it requires a political will to bring about social change. The danger for the field of peace studies comes from the tendency to focus on peace-keeping and peace-making (in a technical sense) to the exclusion of peacebuilding. This can have the function of maintaining the status quo and leaving structural and cultural violence unchallenged.

More recent critiques of the field of peace studies have taken these concepts further. GurZe'ev (2011) is critical of modern concepts of peace that promote suffocating homogeneity, security, assimilation, false ideals and limited horizons. He cites the Jewish philosopher Levinas who rejects peace which, "marvel of marvels - commands humans without forcing them or combatting them, which governs them or gathers them together without enslaving them, which through discourse, can convince rather than vanquish" (Levinas, 1996: 162, cited in Gur-Ze'ev, 2011: 211). This 'peace' creates the Other as an object of education, destruction, redemption and emancipation, all carried out by 'good' parents, 'devoted' 
teachers and 'supportive' friends, who, "produce[s] brave warriors to protect its fears and destroy its internal and external enemies". This is a classic means-end dualism, with the methods of war and propaganda used to further the ends of peace. When peace is grounded in hegemonic practices and a lack of concern for diversity, it becomes the very opposite of itself.

Dietrich (2012) has also argued that moral and modern concepts of peace are incomplete and therefore potentially 'violent'. The dominant Western view of peace builds on universalizing and idealist notions of one peace, one justice, one truth. It excludes non-Western traditions and ways of knowing. Dietrich has identified 'many peaces' grouped into five categories: Energetic peace; moral peace; modern peace; postmodern peace and trans-rational peace. Whilst moral, modern and postmodern peaces are mainly to be found in the West, energetic interpretations of peace grounded in ancient traditions of the great goddess, Tao and Tantra are mainly to be found in the global East and South.

Tao and Tantra aim to free the mind from the games of the intellect, and the illusions and disconnections that undermine peace. They use a human being's physical, psychic, intellectual and spiritual capacities to experience connection between the inner and the outer world of the body and the cosmos. Tantric metaphysics, whether in the Hindu or Buddhist traditions, unite all dualities or polarities. It is assumed that the universe is formed by the polarity of active and passive, female and male, Shakti and Shiva. The energy that flows between them is life:

To unite them and actualise them in the ritual implies visiting the inner Mountain Lake - peace. Tantric practice is thus a spiritual and mystic path which is based on metaphysical assumptions, yet at the same time follows a very practical goal of peace, namely the sublation of all dualities.

Dietrich, 2012:35

According to Murithi (2102) most African societies have likewise developed rich cultural traditions for preserving harmony, and maintaining peace by cultivating group solidarity. This is referred to as 'Ubuntu' in many parts of Africa, especially among the Bantu languages of East, Central and Southern Africa, and is, "a cultural worldview that tries to capture the essence of what it means to be human" (Murithi, 2012:283).

As Dietrich points out, moral and modern concepts of peace are much narrower than this. The dualism of male and female is seen as insurmountable, and the assessment of good and evil does not reside in relations between human beings, but with the creator-god. Truth and justice become singular concepts. Moral and modern interpretations of peace are grounded in pax, the Latin word for peace, the absence of war. This concept of peace is deeply embedded within warrior ethics, fear and in/security. When societies become afraid of thieves, economic change, disease and death, they also become afraid of love, freedom, change, and the unknown, "They live in constant anxiety, chronic hypochondria. They 
become defensive, hard, mistrustful, lonely, and driven by the need to have more" (Dietrich, 2012:89). Moral and modern peace are intimately connected to war and conflict. They are the flip side of the coin, each sustaining the other, neither capable of resolution, both suggesting negative rather than positive peace. This way of thinking is grounded in irreconcilable dualities. It necessitates the exclusion and the persecution of the Other. This is the opposite of peace, and describes a pervasive way of being that dominates in the West.

Writing about research more generally, Lincoln and Denzin (2000) also suggest that the modern interpretation of peace is not longer fit for purpose, due to its inability to encompass diversity:

The Modernist dream of a grand or master narrative is now a dead project. The recognition of the futility and oppression of such a project is the postmodern condition. The postmodern project challenges the modernist belief in (and desire to develop) a progressive program for incorporating all the cultures of the world, under a single umbrella. The postmodern era is defined, in part, by the belief that there has been no single umbrella in the history of the world that might incorporate and represent fairly the dreams, aspirations, and experiences of all peoples.

Lincoln and Denzin, 2000:1055

This diversity needs to be taken into account by those in the field of peace studies. If peace is merely conceived of as 'pax', then crises of legitimation and representation will not go away. To use Galtung's (1969) concept of negative and positive peace, there is a renewed need in the twenty first century to build positive peace through focusing on the kinds of structural and cultural violence that inhibit a genuine sense of global diversity and 'many peaces'. Similar issues can be found in the field of education.

\section{2:2 The Crisis of Education}

The second little word in crisis is education. As Pring (2013) points out, although 'selling' education to young people and their parents for several decades has been about promising better jobs, greater social mobility and rising living standards, this has proved an empty promise for many. The dream of knowledge work for young people in the developed world, supported by manual labour oversees, has been broken by the cold reality that this work too is now being exported. Perry and Francis showed in 2010 that social class continues to be the largest predictor of educational achievement, and that the educational gap between the rich and the poor in the UK, for example, is one of the most significant in the developed world. Thrupp and Tomlinson (2005) list various factors that work against social justice through education in the UK, including the retention of overtly selective policies, the encouragement of covert selection via a diversity of specialist schools and semi-privatised academies, the absence of attempts to challenge the dominance of private schools, and policies of privatisation of schools, local education authorities and educational services. The result is, "the increased social segregation of English schools and higher education institutions" (2005:552). 
Bauman (2012) suggests that the linking of social mobility and education served for many years as a fig leaf for naked and indecent inequality. For as long as academic achievement was correlated with economic reward, "people who failed to climb the social ladder had only themselves to blame" (2012:72) and this took away the moral need to act. Apple (1995:ix) argues that the political Right in the US have benefitted from the social mobility myth. He cites one of its major 'achievements' as having shifted the blame, for unemployment and economic stagnation- "from the economic, cultural and social policies and effects of the dominant group to the school and other public agencies". Similarly, in England, Pring (2013) points out that it is in the interests of ministers and policy makers to hold schools and colleges responsible for the effects of wider social problems, because it passes the blame to others than themselves, and because it makes the solutions look simpler than is really the case.

Education is therefore in crisis because it has failed to bridge the growing gap between the rich and the poor, despite what is claimed. It is also in crisis for other reasons. Most notably, processes of marketization have resulted in education being reduced to a commodity to be consumed like any other. This has diminished its potential as a process of human growth and spiritual development. At a global level, politicians have encouraged students and their parents to view themselves as atomised citizen-consumers who are more interested in the outputs of education than in processes of learning. Lave and Wenger (1991) speak of, "conflicts between learning to know and learning to display knowledge for evaluation" and the ways in which regimes of testing become, "a new parasitic practice, the goal of which is to increase the exchange value of learning independently of its use value" (Lave \& Wenger, 1991:112). Biesta (2014) refers to this as a process of 'learnification'.

Education can thus be an unfulfilling and shallow process that does little to prepare young people for their future roles in society. All too often, it reproduces power relations, and serves to limit, rather than increase opportunities. Clive Harber (2004) in his book Schooling as Violence puts it succinctly:

Throughout the history of schooling there has always been a conflict between education for control in order to produce citizens and workers who are conformist, passive and politically docile on the one hand, and those who wanted to educate for critical consciousness, individual liberation and participatory democracy on the other. It is the contention of [the author] that the former has dominated the real world of schooling... the global persistence of the dominant authoritarian model suggests that the original purpose of control and compliance is deeply embedded in schooling and is highly resistant to change as a result.

Harber, 2004:59

Education, then, has generally failed to bring about social justice at a local and global level. It mainly serves the needs of dominant groups in society, and it has largely failed to bring about participatory democracy and critical consciousness. Regimes of testing and accountability have resulted in an impoverished view of what it is to know and be able to do, and have fore- 
grounded the content of the curriculum at the expense of processes of learning. Education suffers crises of legitimation and representation grounded in structural and cultural violence.

Unfortunately, direct violence is also part of the crisis in education. Internationally, research into violence in schools has been growing steadily (Devine 1996, Olweus 1999, Smith 2003 , Cowie, 2007). In 2003, Smith reviewed levels of violence in schools in Europe through an initiative of the European Commission under its Fifth Framework programme of research activities, which aimed to gain an overview of violence in schools in the fifteen member states at the time, and two associated states. Smith's research showed alarming and increasing levels of student-student and student-teacher violence. In French secondary schools, for example, during 1999 a total of 240,000 incidents were registered with central government, with 6,240 of these regarded as serious. The aggressors were mainly students, as were the victims. In Austria, studies found that around $12 \%$ students admitted to bullying other students regularly or often. In the Netherlands a nationwide random survey found that $22 \%$ students had been victims of sexual harassment by boys at least once, and $43 \%$ had been a victim of intentional damage to property. The Portuguese government Security Cabinet saw up to $14 \%$ increases in reports of violence between 1995 and 1998.

Internationally, direct teacher-student violence in schools may not be as rare as many would hope, although research in this area is lacking. Harber (2004) points out that schools have always sanctioned and legitimized direct violence against children, and that corporal punishment in schools is still regularly used in between one third and one half of all countries in the world, including in some parts of the USA. Harber links schooling with sexual abuse, and gives examples from sub-Saharan Africa, Ireland, Britain and Japan. In Japan reports of sexual misconduct by teachers in schools rose tenfold between 1998 and 2000. In the Rwandan genocide of 1994 when up to a million people were murdered in the space of a few weeks, teachers from a Hutu ethnic background commonly denounced their Tutsi students to the militia or even directly killed them. A South African Medical Research Council survey carried out in 1998 found that among those rape victims who specified their relationship to the perpetrator, $37 \%$ said their school teacher or principal had raped them.

Table One ${ }^{1}$ summarises some of the ways in which direct, structural and cultural violence operate in schools.

Table One: Direct, structural and cultural violence in schools

\section{2:3 The Crisis of Peace Education}

\footnotetext{
1 This table is taken from Guilherme \& Cremin (in press)
} 
Before reviewing the crises of legitimation, representation and praxis in research, this article reviews the crisis that occurs when the concepts of peace and education are combined to form peace education. How legitimate is peace education if it is embedded within systems of schooling that are structurally or culturally violent (Page, 2008)? If peace education aims to create unity, harmony and wholeness, then it undermines the legitimacy of the ground on which it stands if it compartmentalises knowledge into fields and disciplines, and students into groupings based on age, ability, social class or religious belief (directly or indirectly). Toews and Zehr (2003:269) call for peace education that, "emphasize(s) connectedness above separation and healing rather than suffering".

Kathy Bickmore, reflecting on the ways in which cultures of schooling undermined her peace education work over a number of years in state schools in Canada, highlights a related concern that peace education programmes often fail to take a genuine account of diversity or to teach students how to create dynamic peace:

The non-violent confrontation of ... conflicts is what sustains both democratic civil society and human relationships.... Unfortunately typical urban public schools in Canada today do not embrace such conflicts as opportunities for learning and collectively creating dynamic peace. On the contrary despite many notable shining exceptions these schools seem much more often to ignore or actively repress expressions of difference in both implicit and explicit curriculum, focussing their efforts of achieving negative peace through control and conformity.

Bickmore, 2011:99

Bekerman and Zembylas (2012:26) point to romanticism and misrepresentation within peace education, and a lack of theorising which leads to, "functionalist, psychologised and often idealised perspectives". In line with the arguments above concerning the need to recognise 'many peaces' within the field of peace studies, they suggest that advocates of peace education need to critically approach the epistemological and metaphysical certainties of western modernity, and the global inequalities that sustain conflict, violence and injustice. Peace educators need to be aware of whom they speak for, and whom they do not. They need to question how 'world peace' can be taught when so many people remain unrepresented, and when there is no global agreement about what would constitute lasting world peace.

Some see critical peace education as the way forward for dealing with these issues and avoiding the reproduction of powerful hegemonies. Bajaj \& Brantmeier (2011:221) suggest that critical approaches in peace education empower learners as transformative change agents who, "critically analyze power dynamics and intersectionalities among race, class, gender, ability/disability, sexual orientation, language, religion, geography, and other forms of stratification". It is questionable, however, whether all young people can / want to / should be made to engage in these critical practices. The aims and purposes of education are deeply contested, and critical awareness is not universally accepted as an educational aim. Put simply, are diverse young people better served through engaging with an academic 
curriculum grounded in the kinds of 'powerful knowledge' that global elites provide for their own children (Oakeshott, 1989), or through engaging with a curriculum grounded in critical peace education? It could be argued that it is precisely those who are least likely to engage in the latter type of curriculum who will become the decision-makers of the future. It is also those who are least likely to engage in a traditional academic curriculum that have the greatest need for the traditional academic qualifications that could enable them to make a difference to their own lives and the lives of others.

James Page points out that conservative values are just as much part of peace education ethics as radical or critical perspectives. Peace theorists such as Kenneth Boulding (1962) have argued that societal change should be incremental rather than revolutionary because of the risk of violence and anarchy. This more cautious approach does not have to be caricatured as support for structural violence. Rather it can be seen as an appropriate and proportional response to the need for societal change, "because [anything] other than ordered change can easily undo the social fabric upon which social (and indeed international) peace relies" (Page, 2008:116).

Further, Gur-Ze'ev (2011:119) argues that critical narratives run the risk of entering the same, "hegemonic realm of self-evidence" as that occupied by those they seek to unsettle. "Oppressive collectivism and emancipating cruel critiques" can reproduce, "counter-violence of the oppressed" that takes its legitimacy from past injustices. Narratives that create binaries of "us" and "them", "the oppressor" and "the oppressed", and that position peace educators and their disciples as agents acting against powerful individuals and groups, risk reproducing the flawed logic of broken modernist grand narratives. Interpersonal, local and global relations are much more complex and interrelated than this would imply. There is no enemy out there to be conquered - even peacefully - the enemy is within as well as 'out there' and a certain degree of reflexivity and self-awareness are crucial to avoid dramatic oversimplification and hypocrisy.

It is pertinent to wonder with Gur-Ze'ev (2011:105) what is to be learnt here from, "the tension between the explicit aims and the unconscious and sometimes wordless telos of peace education?" Strikingly, he asks further, "What is it that peace education veils, symbolises, works for, and is a naïve agent of?" These are questions that go to the heart of the field. Gur-Ze'ev even suggests that peace initiatives, poorly conceived and executed, can become an extreme manifestation of successful terror. He warns that responsible peace education is more demanding, traumatic and dangerous than peace educators (including critical peace educators) appear to imagine.

The crisis of praxis in peace education is not limited to work in schools. One example is coexistence programmes that target people who are emerging from situations of direct conflict. 
Hantzopoulos, (2011) notes that these programmes have proliferated in recent times, but that, whilst they attract media attention and funding and appear to offer common-sense solutions, they are rarely subject to scrutiny. Of concern are the motivations of different actors in the process, and the ways in which projects are evaluated, especially where larger asymmetrical power relations define the broader landscape. Hantzopoulos, (2011:36) suggests that, "it is clear that identity-based encounter programmes may potentially cause more damage than intended", before reflecting on the need to move away from contrived spaces for inter-group conversation towards more organic opportunities for exchange.

Hantzopoulos gives an example of a Palestinian interviewee who would not participate in a dialogue program, explaining that he is not willing to sit down in the same room as his enemies, as this would accord them a legitimacy that he does not feel they deserve. An issue for programmes such as this is the implication that conflict and violence are somehow the result of a lack of rationality, motivation to change, empathy, or skill on the part of the people affected. This assumption is structurally and culturally violent. It is as if those who have been at the sharp end of conflict (who are often poor and dispossessed) can address problems of violence and inequality through straight and skilful talking. It is as if those who have studied these matters (but not lived with them) can put people back on the right track through providing opportunities for rational dialogue. These initiatives position the participants in such programmes as 'noble savages' who have lost their way, and facilitators as 'hero innovators' with a box of tricks at their disposal. This is particularly concerning if the box of tricks is made in the West, and does not build on indigenous ways of knowing. These damaging assumptions contribute to the very problems they set out to address when peace education is used as a sop to avoid consideration of socio-political drivers of conflict, violence and inequality.

Harris (2004) suggests that the field of peace education has become fragmented and that teachers, schools and education systems have found new words and concepts that are easier to work with in the twenty first century. I would suggest however, as implied above, that the crisis goes deeper than questions of terminology and categorisation. The beginnings of a new model of peace education will be tentatively proposed in the final section of this article.

\section{2:4 The Crisis of Research}

The third little concept in crisis is research. It is worth noting, however, that research is always defined within the parameters of the paradigm in which it sits, and by the epistemology of its researchers. Not all research is consciously in crisis. It depends on the questions that a piece of research aims to address. To some extent, research gains or loses legitimacy from the context that surrounds it. Research investigating whether there is a gene that predisposes an individual to crime, or intelligence, or homosexuality, for example, may have legitimate 
aims and processes, but be lacking in overall legitimacy. Whilst a false distinction is often made between quantitative and qualitative research, the following discussion relates more strongly to emancipatory qualitative research for social justice and peace than it does to large-scale survey-based or experimental research. The issues with these kinds of research are related but different.

It is striking how much of the discussion to follow replicates that which precedes it. Atkinson et al. (2003) and Lincoln and Denzin (2000) note that the crisis of legitimacy in qualitative research is essentially provoked by the modernist assumption that the researcher is somehow a bloodless angel floating above the world under investigation, capable of cool objectivity (Maclure, 2013). Contemporary qualitative researchers are increasingly unsettled by the notion of a researcher (typically white, middle class, male), representing a homogenous community of their peers. They question the legitimacy of information and recommendations passed on to users of research, and the capacity of research users to act in the interests of socially-excluded people (typically ethnically diverse, poor, female). They recognise that all texts are socially, historically, politically, and culturally located, and that "we, like the texts we write, can never be transcendent" (Lincoln and Denzin, 2000:1058). Rather than seeing the traditional subjects of social science as somehow 'out there' to be explored, Denzin and Lincoln's contemporary qualitative researcher sees racism, war, sexism, poverty, homophobia and disability as issues that touch all of us, "We can't hide from them. We are all complicit in some way. No one is immune, invulnerable" (Ellis \& Bochner, 2000:748).

The crisis of legitimacy questions the ways in which (just as in the field of peace studies) modernist narratives position social and political problems as errors in logic, empathy or information flow. It is as if people simply need to be told what they are doing wrong, so that they can change their behaviour. The poor need to learn how to be more like 'us', and dominant groups in society need to be informed about the consequences of their actions so that they can make necessary changes. This modernist view of the world is patronising, lacking in self-awareness and vastly underestimates powerful socio-cultural, political and economic networks, as well as issues of sustainability and the complexity of human decisionmaking.

Edward Said's Orientalism in 1978 was a key text in invoking the crisis of representation. In it, he denounced the dualisms that juxtapose Western rationality, objectivity, and science with Oriental irrationality, subjectivity, magic, religion, and adherence to tradition. He rendered increasingly problematic the relationship between the researcher and the researched, and challenged researchers to find new ways of studying others that do not describe their otherness in terms that reproduce hegemonic relationships and representations. 
The preceding argument builds on the idea that, as "communicating humans studying humans communicating", we are inside what we are studying (Ellis \& Bochner, 2000:743). Qualitative research, and ethnographic research in particular, requires the researcher to become intimately connected to people in the field in ways that make cool objective research both impossible and undesirable. Contemporary ethnographers are increasingly exploring, and even celebrating, relations of intimacy in the field. Many are treating close relations (such as their own family members) or personal transformations (such as religious conversions) as legitimate topics for scholarly research. This has particular implications for peace researchers. Inner peace becomes just as important a field of exploration as outer peace.

It is evident, then, that processes and practices of qualitative research need to evolve to take account of the new landscape, and to recover the values that were lost in the grand narratives of modernism. Page (2008: 20) draws on the hermeneutics of Gadamer to suggest that we need to engage with the "rehabilitation of prejudice and rehabilitation of subjective commitment". What this will look like is not yet fully clear. As Lincoln and Denzin (2000) point out:

The Old Story will no longer do, and we know that it is inadequate. But the New Story is not yet in place. And so we look for the pieces of the Story, the ways of telling it, and the elements that will make it whole, but it hasn't come to us yet. So we are now the ultimate bricoleurs, trying to cobble together a story that we are beginning to suspect will never enjoy the unity, the smoothness, the wholeness that the Old Story had.

Lincoln and Denzin, 2000:1060

They look towards a form of qualitative enquiry in the $21^{\text {st }}$ century that is minimal, existential, autoethnographic, vulnerable, performative, and critical. They call for research that grounds the self in a sense of the sacred, and in an ethical, respectful and dialogical quest to understand nature and the worldly environment. Ellis and Bochner (2000) equally emphasise the spiritual and artistic nature of new processes of research. Within the writings of postmodernists, feminists and queer theorists there is a renewed appreciation for emotion, intuition, personal experience, embodiment, and spirituality. "They've helped us cross some of the boundaries separating the arts and the sciences and to focus attention on diversity and difference instead of unity and similarity" (Ellis and Bochner, 2000:748).

These new methods also relate to praxis, and the ways on which research can become more sensitive to outcomes, whether intended or unintended. Rather than agonising about questions of validity and reliability, the merits of research narratives can be judged in the same ways that authors or characters are judged, 'Is the work honest or dishonest? Do we gain a sense of emotional reliability? What are the possibilities for new ways of living in peace? Does the story help in understanding the experience it seeks to convey?' (Ellis and Bochner, 2000: 746).

\section{2:5 The Crisis of Peace Education Research}


Finally, combining all of the three concepts of peace, education and research, peace education research is reviewed here as positioned at a crossroads. The crises in peace, education, peace education and research could be amplified if peace education researchers are not reflexive and mindful. The field of peace education research requires particular attention to be paid to methodology. There is a need for methodology to avoid reproducing the kinds of structural and cultural violence that peace work seeks to address. With Toews, Howard Zehr, the highly respected grandfather of the restorative justice movement, calls peace researchers to account:

Unfortunately, in our research practices we often fail to operate under principles that are consistent with our beliefs in restorative justice and instead mirror the values of the dominant justice system. Like justice professionals, as researchers we view ourselves as objective experts in the field, assuming responsibility for the stories of the people we study. We collect data and stories, interpreting the meaning without consulting or giving benefit to our subjects.

Toews and Zehr (2003: 257-88)

The need for peace research to benefit participants as much as researchers is central here. Writing about research with Native participants, Rogers Stanton (2014) found that power and control remained largely with the researchers, even within Community-Based Participatory Research. Rogers Stanton notes that, "the Native participants in the example project emphasized a tendency for scholars to share information solely for their own prestige, as opposed to seeking a broader paradigm shift within academia and/or providing a direct service to the Native community" (Rogers Stanton, 2014:576). Even here, where comprehensive collaboration was integral to the research at a theoretical level, various logistical influences meant that it was not fully achieved. Throughout the project, Rogers Stanton, "struggled with the discomfort associated with an emphasis on difference, which historically has encouraged hierarchical and dichotomizing categorization within Western research contexts" (Rogers Stanton, 2014:580).

Toews and Zehr (2003) urge researchers to shift priorities to benefit the communities in which research is carried out, rather than the policy-makers and funders who so often use the work for their own ends. They call for a new civic social science that could signal the end of meansends dualism. Drawing on restorative values, as well as the emerging methodologies in qualitative research, they propose a new form of 'transformative inquiry'. Transformative inquiry should aim at social action more than 'pure' knowledge, and acknowledge that much knowledge is subjective, constructed and inter-relational. It should recognise the complex and limited nature of research findings and take full account of the power dynamics inherent in all research. Transformative inquiry should respect subjects as participants in the study, and define the researcher as facilitator, collaborator and learner, rather than neutral expert. It should value process as much as product, and acknowledge that the researcher is open to being affected personally by interaction with others. Transformative inquiry should be attuned to potential harms and unintended consequences for subjects and others, and avoid co-option 
by funders, clients, colleagues or others. Through transformative inquiry the researcher invites participants to tell their personal stories and creates space for their voices to prevail. Thus, through their storytelling, "we learn not only of the similarities and uniqueness among people but also of our connectedness to those around us" (Toews and Zehr, 2003:269). This is fundamental for de-colonizing the practices of peace education research.

\subsection{Summary of the Five Interrelated Crises}

Table Two below summarises these arguments concerning the crisis of legitimation, representation and praxis in peace, education, peace education, research and peace education research, and frames them as challenges that need to be responded to. It is clear from this that much is to be gained from considering these crises alongside each other.

\section{Table Two: Summary of Five Interrelated Crises}

\subsection{Looking to the Future of Peace Education and Peace Education Research}

This article has responded to llan Gur-Ze'ev's call to rethink peace education in the light of post-structuralist objections, but so far has not considered the opportunities for the future of peace education to any great extent. This will be the subject of on-going research and writing, but in the meantime two fruitful areas present themselves. Firstly, the need to operationalize Galtung's foundational theories in peace studies through stronger ties to practice, and secondly the need to include aesthetic traditions within a more integrative approach to peace education.

\subsection{Building on Galtung's legacy}

Galtung's theories of peace and violence remain central to the field of peace studies. They can, however, be extended to take account of the crisis of representation. One useful contribution might come from Franz Fanon (1963), one of the most prominent thinkers on African decolonisation (Guilherme \& Cremin, in press). So, for example, whilst Galtung understands cultural and structural violence as forms of inter-connected indirect violence, Fanon (who was a trained psychiatrist) sees psychological violence as having direct and disastrous effects on colonised populations. This perspective can help deepen awareness of the ways in which violence plays out in colonised settings, and opens up discussion about the direct and invidious effects of 'othering'. Due to a lack of space here, readers are pointed towards Guilherme \& Cremin (in press) for a wider review of these issues.

In a similar vein, Bourdieu's (1986) notion of symbolic violence arguably offers a more practical foundation for applied research than Galtung's theory of structural and cultural 
violence. Whilst Galtung's theory has been criticized for being too abstract (Boulding, 1977), Bourdieu's theory of symbolic violence contains useful conceptual tools, such as habitus and cultural capital, which can be operationalized in the field. It also offers a framework for greater reflexivity amongst practitioners and researchers. Again, Kester \& Cremin (in press) offer a wider discussion of these possibilities.

\subsection{Aesthetic peace education}

Another promising set of theories relate to aesthetic peace (Page, 2008). Linked concepts are Ghandi's Satyagraha; Gur-Ze'ev and Rozenzweig's hospitality, co-poesis and improvisation (2011); Buber's I-Thou relations (2004, 1937); and Dietrich's energetic peace (2012, later transrational peace). These value inner as well as outer peace, and integrate Eastern, Western and indigenous perspectives on peace. They draw on the arts and spirituality (widely conceived) and point to research that would be in line with Lincoln and Denzin's 'seventh moment' discussed earlier (Lincoln \& Denzin, 2000).

Aesthetic peace is derived from aesthetic ethics. In a review of the philosophical lenses through which peace education can be viewed, Page (2008) identified virtue ethics; consequentialist ethics; conservative political ethics; aesthetic ethics; and the ethics of care. He suggests that aesthetic ethics have been on the resurgence in recent times due to increased planetary awareness brought about by space travel and awe-inspiring images of Gaia sent back to Earth. He includes philosophers such as Plato, Augustine, Aquinas, Hume, Adam Smith and Ghandi as aesthetic philosophers, and also includes Hebrew, Islamic and Buddhist religious writings. He draws on Bernard Haring and Valentino Salvoldi, who have argued that education for peace is not so much a task to be implemented as a process of educating the body to be in dialogue with the senses, and also on Sherry Shapiro who, "sees peace education as encouraging a bodily orientated passion for peace and justice" (Page, 2008:156). He goes on:

If we believe that peace, that is, harmonious and co-operative relations between individuals and societies, is a beautiful thing, a valuable thing in itself, then we should not be reticent in encouraging this as a stated objective for education.

Page, 2008:158

This suggests new approaches to peace education that integrate body, mind, heart and spirit, and will be the subject of future articles. Gur-Ze'ev draws on Franz Rosenzweig and Martin Buber to suggest an aesthetic of peace that is grounded in the imminent space of the nomad, and the liminal space of diaspora (2011). It is very different from the colonising and territorialised spaces of the past. Rosenzweig calls for, "the hospitality of Diasporic life; an alternative co-poeisis... amid nomadism, which replaces 'peace' as standstill in the form of continuity with peace as the hospitality of... enduring improvisation of the one who actualises eternal creative moral responsibility every moment anew" (Gur-Ze'ev, 2011:113). As Gur- 
Ze'ev points out, the absence of tranquillity and of homogeneity is here of special importance, as is the honouring of space, voice, sound, movement, visibility, smell and contact. He suggests that the absence of 'peace' and the overcoming of the illusion of peace are the birth moment of an alternative togetherness characterised by responsible improvisation and creativity.

Buber's (2004) aesthetic of peace is one of relationality. He bases his philosophy on the fact that human beings are constantly in relation to each other or the world. They can either relate to others as I-It (as objects) or as I-thou (as fellow subjects). God occupies the space between (the hyphen) when I-thou relations are established. He does not exist outside of that, as a separate entity. Buber argues that the I-Thou relation lacks structure and content because infinity and universality are at the basis of the relation. (Guilherme and Cremin, in press). He understood that human existence consists of an oscillation between I-Thou and IIt relations, and that I-Thou experiences are rather few and far between. Following Buber, Guilherme and Cremin (in press) suggest that an 'epistemological shift' needs to take place in peace education in order to create the conditions where I-Thou relations become more likely; that is, where human being cease seeing the Other as an It. It is only when this 'shift' occurs that Galtungs's peace-keeping can switch to peace-making and peace-building.

Wolfgang Dietrich's transrational aesthetic of peace is particularly useful here (2012). Many new and emergent concepts of peace education use prefixes such as post- or counter-, but these replicate binary and reactive thinking, and tie the approaches in with the traditions that precede, constrain and define them. Dietrich quite rightly points out that postmodern peace education is only relevant to counties that have experienced modernity, and that much of the world (notably India) has never been subject to modernity, and therefore cannot really be seen as postmodern.

The prefix trans- , however, suggests a different aesthetic, a horizontal aesthetic of journeying; of being both in and beyond. Whilst conventional linear concepts of time are characteristic of a modern understanding of peace, transrational peace conceives of time as inextricably connected with the observer in the same way that Quantum physics does. Transrationality is created when one accepts the limits of Western logocentrism, but engages nevertheless in a quest for truth that integrates inner and outer peace in a process of constant journeying. The contradiction between the autonomous subject of the Enlightenment on the one hand, and the collective yogic mind on the other, loses its distinction when viewed through the lens of theorists such as Dietrich and Erich Fromm, who defined transrational harmony as, "the full realisation of a human being's reason until a state in which it no longer keeps her / him from immediately and intuitively grasping nature" (Dietrich, 2012:255). The spirituality of Einstein comes to mind. 
Transrational peace research is concerned with the inner self, not the persona or the exterior mask. It begins with an inward gaze, just as learning to be a psychotherapist does. It integrates spirituality and rationality, and is not limited to either. Transrationality, "does not deny rationality. It also does not overcome it, but crosses through it and adds the aesthetic component that is always inherent in interpersonal relations but that has not been observed that attentively by modernity" (Dietrich, 2012:266). It can be seen, not as a denial of enlightenment ideals, nor as a rejection of postmodern critique, but as a completion of all of them in a mature global ethics that is free from universalised norms.

\subsection{Conclusion}

This article begins with the Japanese symbol for crisis, which encompasses both danger and opportunity $^{2}$. It has argued that peace, education, peace education, research, and peace education research all face inter-connected crises of legitimation, representation and praxis. It has gone on to suggest that emergent themes in research, peace studies and peace education point to significant opportunities for growth and development. Most notable amongst these are opportunities to work towards more genuinely global, integrative and diverse notions of world peace made up of 'many peaces', which include arts-based traditions of research and narrative, and the aesthetics of peace. The integration of inner and outer peace, as represented by Dietrich's inner mountain lake, is an ancient global tradition that perhaps points towards new opportunities.

\section{References}

Apple, M.W. (1995) Education and Power, New York: Routledge

Atkinson, P., Coffey, A \& Delamont, S. (2003) Key Themes in Qualitative Research:

Continuities and Changes, Oxford: AltaMira Press

Bajaj, M. \& Brantmeier, E. (2011): The Politics, Praxis, and Possibilities of Critical Peace Education, Journal of Peace Education, 8,3, 221-224

Bauman, Z. (2012) On education: Conversations with Riccardo Mazzeo, Cambridge: Polity Press

Bekerman, Z. \& Zembylas, M. (2012) Teaching Contested Narratives: Identity, Memory and Reconciliation in Peace Education and Beyond, Cambridge: Cambridge University Press

Bickmore, K. (2011) Education for "Peace" in Canadian Schools. In P.P. Trifonas, \& B. Wright, (Eds) Critical Issues in Peace and Education, New York: Routledge

2 With Thanks to Terence Bevington for sending this to me. 
Biesta, G. (2014) Pragmatising the curriculum: bringing knowledge back into the curriculum conversation, but via pragmatism, The Curriculum Journal, 25,1, 29-49

Boulding, K.E. (1962) Conflict and Defense: A General Theory. New York: Harper and Rowe:

Boulding, K. E. (1977) Twelve Friendly Quarrels with Johan Galtung, Journal of Peace Research, 14, 1, 75-86

Bourdieu, P. (1986). The Forms of Capital. In J. Richardson (Ed.), Handbook of Theory and Research for the Sociology of Education, New York: Greenwood Press, 241-258

Buber, M. (2004, 1937), I and Thou, New York: Continuum.

Cowie, H. \& Jennifer, D. (2007) Managing Violence in Schools: A whole-school approach to best practice, London: Paul Chapman Publishing

Cremin, H., Sellman, E., and McCluskey, G., (2012), "Interdisciplinary Perspectives on Restorative Justice: Developing Insights for Education", in British Journal of Educational Studies, Vol. 60, No. 4, pp. 421-437.

Devine, J. (1996) Maximum security: The culture of violence in inner city schools, Chicago: University of Chicago Press

Dietrich, W. (2012) Many Peaces: Interpretations of peace in history and culture, New York: Palgrave Macmillan

Ellis, C. \& Bochner, P. Autoethnography, Personal Narrative, Reflexivity. In N. Denzin \& Y. Lincoln (2000) Handbook of Qualitative Research (second edition) London: Sage

Fanon, F., (1963), The Wretched of the Earth, New York: Grove Weidenfeld.

Galtung, Johan (1969). Violence, peace, and peace research. Journal of Peace Research 6 , 3, 167-191.

Guilherme, A. \& Cremin, H. (in press) Violence in schools: Perspectives (and hope) from Galtung and Buber, Educational Philosophy and Theory

Gur-Ze'ev, I. (2011) Improvisation, Violence and Peace Education. In P.P. Trifonas, \& B. Wright, (Eds) Critical Issues in Peace and Education, New York: Routledge 
Hantzopoulos, M. (2011) Encountering Peace: The politics of Participation when Educating for Co-Existence. In P.P. Trifonas, \& B. Wright (2011, Eds) Critical Issues in Peace and Education, New York: Routledge

Harber, C. (2004) Schooling as Violence, Abingdon: RoutledgeFalmer

Harris, I.M. (2004) Peace education theory, Journal of Peace Education, 1, 1, 5-20

Kester, K. \& Cremin, H. (in press) Pedagogic Discourse within Peace and Conflict Studies in Higher Education: Critique and New Possibilities, Journal of Peace Education

Lave, J. \& Wenger, E. (1991) Situated Learning: Legitimate peripheral participation, Cambridge: Cambridge University Press

Levinas, I. (2006) Peace and Proximity. In A Peperzak, S. Critchley, \& R. Bernasconi (Eds) Immanuel Levinas: Basic philosophical writings, Bloomington: Indiana University Press

Lincoln, Y. \& Denzin, N. (2000) The Seventh Moment: Out of the past In N. Denzin \& Y. Lincoln Handbook of Qualitative Research (second edition) London: Sage

Maclure, M. (2013) Researching without representation? Language and materiality in postqualitative methodology, International Journal of Qualitative Studies in Education, 26, 6, 658667

Murithi, T. (2012) Peacemaking and African Traditions of Justice and Reconciliation. In Nan, S.A., Mamphilly, Z.C. and Barloti, A. (eds) Peacemaking: From practice to theory, Oxford: Praeger

Oakeshott, M. (1989) The Voice of Liberal Learning, New Haven: Yale University Press

Olweus, D. (1999) Sweden. In P.K. Smith, Y Morita, J. Junger-Tas, D. Olweus, R. Catalano and P Slee (Eds.) The Nature of School Bullying: a cross-national perspective. London: RoutledgeFalmer

Page, J (2008) Peace Education: Exploring Ethical and Philosophical Foundations, Charlotte NC: Information Age Publishing

Perry, E. \& Francis, B. (2010) The social class gap for educational achievement: a review of the literature, London: RSA 
Pring, R. (2013) The Life and Death of Secondary Education for all, London: Routledge

Rogers Stanton, C. (2014) Crossing Methodological Borders: Decolonizing Community-Based Participatory Research, Qualitative Inquiry 20, 573-83

Said, E. (1978) Orientalism. New York: Pantheon.

Sen, A. (2011, Ed) Peace and Democratic Society, Cambridge: Open Book Publishers

Smith, PK., (2003), Violence in Schools: the response in Europe, London: RoutledgeFalmer.

Toews, B. \& Zehr, H. (2003) Ways of knowing for a restorative worldview. In E.G.M.

Weitekamp \& H-J. Kerner (Eds) Restorative Justice in Context: International Practice and Directions, Cullompton: Willan Publishing, 257-271

Thrupp, M. \& Tomlinson, S. (2005) Introduction: education policy, social justice and 'complex hope', British Educational Research Journal, 31, 5, 549-556

United Nations Children's Fund (2011) The Role of Education in Peacebuilding: A synthesis report of findings from Lebanon, Nepal and Sierra Leone, New York: UNICEF

7,270 words without references

8, 049 with references 